\title{
THE EFFECTIVENESS OF USING TIC TAC TOE GAMES IN STUDENTS UNDERSTANDING ON SIMPLE PRESENT TENSE AT THE FIRST GRADE OF SMPN 1 KABUPATEN SORONG
}

\author{
Nursalim \\ nursalim@unimudasorong.ac.id \\ Rizqi Claudia Wardani H \\ rizqyclaudia@unimudasorong.ac.id \\ Agnesia Ultha Irianti Karraske \\ agnesiakarraske@gmail.com
}

Education University of Muhammadiyah Sorong, Indonesia

\begin{abstract}
Learning simple present tense for student is to present something happen about the situation now, a feeling and to make an opinion. The researcher was investigating and doing the research. This study was to find out whether using Tic Tac Toe game is more effective than using conventional method to make students more understand in simple present tense at first grade students of SMP N.1 Kabupaten Sorong in academic year of 2016/2017. The samples were sixty students from two hundred and forty seven of the population, they are from first grade A as experiment group and first grade $\mathrm{C}$ as control group. The data were collected by pre-test and post test to both of classes. After give the pre-test, the researcher give treatment, the steps of the class activities are; (1)the implementation of the game is the teacher give the key word on the board; (2)the students makes a group to determine be (X) or (O) groups; (3)after that, the students group $(\mathrm{X})$ or $(\mathrm{O})$ will discuss together about the strategy to answer the key word and to win the game; (4)if the students group can not answer or make a wrong answer from the key word, the other groups will be given the chance to answer it. After treatment post test is given to both of groups. The researcher was using quantitative research and quasi experimental as the design. The result of this study showed that use game especially Tic Tac Toe game was effective in student understanding of simple present tense. It showed from the result of post-test in experiment group, that is higher than control class. It could be proved from the result of T-

Test, which is ttest $4,598 \geq$ ttable 2,000 . It means the result test was higher than table so, is refused and is accepted. The researcher concluded that Tic Tac Toe game was effective on student understanding in simple present tense.
\end{abstract}

Keyword :Tic Tac Toe Game, Simple Present Tense.

\section{INTRODUCTION}

Generally, learning grammar is very important to us. We cannot communicate with jumbled sentence. People who are not learn English well will get difficult in constructing sentence although they can communicate with it. Grammar for academic is important like for abstract, paper, reading textbook, journal, or presentation. Learning English consist of four language skills. There are speaking, writing, 
listening and reading. Besides learning about four skills, student must learn about grammar. The government has to apply the English teaching earlier at school, beginning from the elementary school as a local content up to twelfth school grade of senior high school. Then, the main objective of English teaching in junior high school is the learners can master English communication which covers language components: grammar, vocabulary, and pronunciation, with the basic skills: listening, speaking, reading and writing. (Regulation Minister Of Education RI No.22 Year 2006, p.277). There had major skills through language were listening, speaking, reading and writing.

If the people would be success in mastering those skills, there were three components that are actually as the requirements include grammar, vocabulary, and pronunciation. From those components, grammar is considered the most important as it serves as the foundation for more advanced language learning (Cahyono and Widiati 2011: 87). English makes gratify in learning process. Although there are some difficult material, it can be solved by using the good or interesting method that can make the students will not bored and more understand quickly about what the teacher teach to them. For example how to make a correct sentence based on the structure of sentence and so on. People always have ideas, but all of them just had minimum knowledge about grammar and how to explain to their ideas.

Tenses are one of basic grammar taught for junior high school and senior high school. There are many students who get difficulties about how to make a correct sentence on well structured. In addition especially in simple present tense, learner still confused how to put verb in sentence, how to use auxiliaries in negative to interrogative sentence. The student knows using simple present tense to purpose based on factual events and habitual. Grammar in one of an essential part of writing, as it helps to extend the idea where you are trying to get across. Based on adjustment of education by Regulation Minister that writing is one of component in school for learner and it can make them to be mastered in English communication. Most of people using grammar in learning process both in speaking and writing. In this part, the researcher wants to apply writing to make sentences on present tense.

Based on observation the researcher got information from students that if they pay attentions to the teacher's explanation they could understand the material, but sometimes the students had problem in learning English. Some of students get confused how to change auxiliaries from negative sentence to interrogative sentence and how to differentiate the verbal sentence and nominal sentence.

The writer choose this school because according to the teacher who has taught in this school, there are some problems happen in teaching learning process generally, especially in present tense. Students are still confused how to use present tense in a sentence, how to change a word with using good structure, and how to change 
negative sentence to interrogative sentence. Some of students did not like serious teaching learning method. Most of the student opinion stated that English is hard to learn, because there are some differences in sentences. Moreover, English had different sound if you want to speak the alphabet.

Based on the problem, it is important to find an alternative way in teaching learning process and interesting technique for students to make fun on the process learning. So, the researcher offers game Tic Tac Toe to make student understand in present tense, so that students be more enjoy in the teaching learning process. Tic Tac Toe game is a board game that using sign $\mathrm{O}$ and $\mathrm{X}$. In this part where $\mathrm{O}$ and $\mathrm{X}$ are one of way to sign in playing the game, it will make a line. This game can be applied in teaching learning process to make students understand on present tense. Here, the game is used to deliver the materials in order to be more fun for students in the process of teaching learning, so they will be enthusiastic in joining the activity. It is important to use game as an alternative way in teaching grammar. This way can make students also have chance to respond or correct other friends on their exercise. In Tic Tac Toe game, there is any competition and cooperative with team that can make students more be enthusiasm and active in learning.

Using media in game Tic Tac Toe game would be allowed more than one-way communication, the teachers not only give verbal stimulus but also gave a stimulate students to shows their main-set their own. So, in addition allows teachers to explain the subject, the materials by using Tic Tac Toe game also can be attract the attention of the students and can prevent students bored among the material giving in classroom. Based on the description above, the writer is interested in studying about the effectiveness of Tic Tac Toe game in students understanding on simple present tense at the first grade SMP N 1 Aimas, Sorong. Hopefully, this technique can be an effective learning technique in teaching simple present tense and the student more active in learning process.

\section{LITERATURE REVIEW}

\section{Previous Related Study}

The first thesis written by Nur Qomariah (2010), this research had been the main objective,there is to find out the effective or not a significance to improve the students understanding on simple present tense by using card game and those taugh by her self. The writer using design in her study was experimental research design. The population in this study was the first grade and two classes were selected by cluster random sampling as the sample of study. The writer using instrument to collect data was used test, where the technique pre test and post test. There is significant difference between achievement score of students who are taught by using card game and who are taught without using card game is difference. So, it means 
that the usage of card game is effective. Therefore it gave positive effect in improving the students' understanding.

The second thesis written by Maria Ulfah (2011),this research had been the main objective,there is to describe the condition of the effectiveness of students' understanding in simple present tense by dialogue. The population in this study was the first grade at Mts N Tangerang II Pamulang. The writer using design in her study was pre experimental research design. The writer using instrument to collecting data was used observation and test, than that was analyzed by using t-test. The result of this study is effective and quite success by using dialogue technique because it can lead the students to be able to learn simple present tense well.

The third thesis is written by Dewi Chalim (2010), this research had been the main objective,there are to describe the implementation of Tic Tac Toe game to improve students' understanding on simple past tense and to find out the improvement of students' understanding on simple past tense by using Tic Tac Toe game. The population of this thesis was VIII C. The writer using design in her study is a classroom action research. The writer using instrument to collecting the data was documentation, test and observation and then used descriptive quantitative to analyze the data. This thesis is successful and it can be seen from the result of students' average score and good responses by students.

Those three theses written from the thesis above have similarities among:

1. The first thesis above, the researcher makes that using game to know the effectiveness student understanding on simple present tense. The writer used first grade as population in her research. The method of the research used in employing the research that used experimental. Then the technique in collecting the data is used test by giving pre test and post test.

2. The second thesis above, the writer used present tense in her research. The writer used experimental method in her research. The writer choose first grade as her population. The writer also gave the test to collecting the data.

3. The third thesis above, the writer using game Tic Tac Toe in her research. She also using test to collecting the data.

However, the differences are the setting of the study, the participant of the research, the type of the media used in teaching learning and the design where used in the study. In third thesis, the writer used classroom action research in her thesis. This thesis focused on the use of Tic Tac Toe game to know the students understanding achievement in learning English Grammar on Simple Present Tense.

\section{Games}


The teacher must search the good way to make the students be active in learning English. One of the good ways is using game method. Using game can make some atmosphere to push the student hopes in learning language. The student will learning be better if they had a feel that they can progress and the game supply the student chance for evaluate to fade their fear in learning especially in grammar (Richard \& Rogres: 2001, in Ayu and Murdibjono, 2012:5). According to Zuckerman and Horn (1983:380, in Journal of English Language Teaching, Vol.1 No.2, March 2013, Serie C) game is a special category of real things. A game is simplified, operational model of a real life situation that provides student with various participations in a variety of roles and event. It means that game, the teacher invites the students to participate and follow the roles.

In teaching learning also used game to make learning process more fun, especially in learning grammar. There are some kinds of games in teaching grammar:

1. Competitive game, which the game had the players or team race to be the first reach the goal. In this kind of the game the players focus on how to be the winner.

2. Cooperative game, which the players or team can work together toward a common the goal. This kind of the game makes the player or team doing togetherness toward a setting out the cooperation teams. (Nurhajati and Agung in Cahyono and Mukminatien 2011: 40)

Based on the explanation above, it is important to know what the kinds of the game that necessary for the learners. So, the teacher can makes the game should achieve the student. In this research, the game that used on this research was included both of the kinds of game. Where the Tic Tac Toe needed work togetherness with team, and also have to be the first reach in goal before another team be a winner. There are many advantages of game (Kim 1995:35), they are:

1. Games are welcome break from the usual routine of the large class.

2. They are motivating and challenging.

3. Learning a language requires a great deal effort. Games help students to make and sustain the effort of language.

4. Game provides language practice in the various skills.

5. They encourage students to interact and communicate.

6. They create a meaningful context for language use

According to Philpot as cited by Tarwiyah (2008:51), games facilitate language learning because they help language learning to be:

1. More meaningful, for example by showing how words relate to each other.

2. More memorable, for example by involving as many approaches to how language is 'stored' as possible, such as mime, and movement, the use of color and patterns, personalization, etc.

3. More accessible, for example by getting students to make their own language records to suit their individual strategies for reference and access. 
According to some expert above, the researcher concluded that game in learning process gives good effects to activate understanding and memorable especially in learning foreign language classroom. Although there are many advantages of game in language learning, game has disadvantages based on (Habshy, 2009:24). They are:

1. It can present disturbance if teacher cannot control and organize the class to be conducive.

2. It takes a bit long time to prepare.

3. It can cause boredom if teacher uses this game solely, and not all students like playing the game

\section{Tic Tac Toe}

Tic Tac Toe (also well-known as Tick Tack Toe, noughts and crosses, Xs and Os, and many names) is a pencil-and-paper game for two players, called $\mathrm{O}$ and $\mathrm{X}$, who make turns marking the spaces in a $3 \times 3$ grid. The player who succeeds in placing three respective marks in horizontal, vertical, or diagonal rows is the winner (Andyani, 2016: 61). According to Wela Agustia in her Journal Of English Language Teaching, Vol.1 No.2, March 2013, Serie C :227) there are some ways to begin the game. They are:

Strategy to play Tic Tac Toe game

In learning Tic Tac Toe, the teacher had roles. The teacher should consider the strategy before beginning learning process using the game. There are: Preparing the media

To apply this game the important media needed is board. It attracted the students' attention and it also can help student understand the material easily. To play Tic Tac Toe game, teacher can draw at board or bring the big set of paper to student.

1. Preparing the students

The student prepared to give themselves confidence to learn the material. Next, they need to be prepared the topic in general to do the activity.

2. Explaining learning skill

In choosing the language item, the teacher has to explain what to do at a certain point. Although, the teacher is facilitator who can created the activity where the student do not only use the language, but the teacher also helps the student to understanding the reason of knowing something. Tic Tac Toe is one of game where chose as subject.

3. Managing the classroom

The classroom should be a place where learners can write the tenses especially simple present tense based on the structure.

In addition, students also had role, where this game will not run effectively if there is not participant from students. In this game student will work in group. Student will cooperate with another friend in group to play this game. 


\section{METHOD}

\section{Research Design and Procedure}

This research, the researcher used quasi experimental method. To get the beginning data the researcher was going to give pre- test for both of the classes (Experimental and Control Group) at SMP N 1 Aimas. After giving pre- test, then the researcher giving treatment to both of group (Expperimental and Control). In experimental group the researcher give the treatment use Tic Tac Toe game by the method and for control group thte researcher give conventional method. Aftre giving treatment, the researcher give post-test to both of groups to know the compare before and after giving treatment, and to know the compare pre-test and post- test before and after giving the treatment in experimental group. The design is as follows:

$$
\begin{aligned}
& \mathrm{K} 1=\mathrm{T} 1-\mathrm{X}-\mathrm{T} 2 \\
& \mathrm{~K} 2=\mathrm{T} 1-\mathrm{O}-\mathrm{T} 2
\end{aligned}
$$

Note:

$\mathrm{K} 1=$ Experimental group

$\mathrm{X}=$ treatment

$\mathrm{K} 2=$ control group

$\mathrm{O}=$ conventional method

$\mathrm{T} 1=$ pre-test

$\mathrm{T} 2=$ post-test

(Setiyadi, 2006: 135-139)

\section{FINDINGS AND DISCUSSION}

Generally, learning grammar is very important to us. We cannot communicate with jumbled sentence. People who are not learn English well, will still get difficult in constructing sentence although they can communicate with it. Grammar for academic is important like for abstract, paper, reading textbook, journal, or presentation. Learning English consist of four language skills. There are speaking, writing, listening and reading. Besides learning about four skills, student must learn about grammar. The government has to apply the English teaching earlier at school, beginning from the elementary school as a local content up to twelfth school grade of senior high school. 
Then, the main objective of English teaching in junior high school is the learners can master English communication which covers language components: grammar, vocabulary, and pronunciation, with the basic skills: listening, speaking, reading and writing. (Regulation Minister Of Education RI No.22 Year 2006, p.277). There had major skills through language were listening, speaking, reading and writing. If the people would be success in mastering those skills, there were three components that are actually as the requirements include grammar, vocabulary, and pronunciation. From those components, grammar is considered the most important as it serves as the foundation for more advanced language learning (Cahyono and Widiati 2011: 87).

English makes gratify in learning process. Although there are some difficult material, it can be solved by using the good or interesting method that can make the students will not bored and more understand quickly about what the teacher teach to them. For example how to make a correct sentence based on the structure of sentence and so on. People always have ideas, but all of them just had minimum knowledge about grammar and how to explain to their ideas.

Tenses are one of basic grammar taught for junior high school and senior high school. There are many students who get difficulties about how to make a correct sentence on well structured. In addition especially in simple present tense, learner still confused how to put verb in sentence, how to use auxiliaries in negative to interrogative sentence. The student knows using simple present tense to purpose based on factual events and habitual. Grammar in one of an essential part of writing, as it helps to extend the idea where you are trying to get across. Based on adjustment of education by Regulation Minister that writing is one of component in school for learner and it can make them to be mastered in English communication. Most of people using grammar in learning process both in speaking and writing. In this part, the researcher wants to apply writing to make sentences on present tense.

Based on observation the researcher got information from students that if they pay attentions to the teacher's explanation they could understand the material, but sometimes the students had problem in learning English. Some of students get confused how to change auxiliaries from negative sentence to interrogative sentence and how to differentiate the verbal sentence and nominal sentence.

The writer choose this school because according to the teacher who has taught in this school, there are some problems happen in teaching learning process generally, especially in present tense. Students are still confused how to use present tense in a sentence, how to change a word with using good structure, and how to change negative sentence to interrogative sentence. Some of students did not like serious teaching learning method. Most of the student opinion stated that English is hard to learn, because there are some differences in sentences. Moreover, English had different sound if you want to speak the alphabet. 
Based on the problem, it is important to find an alternative way in teaching learning process and interesting technique for students to make fun on the process learning. So, the researcher offers game Tic Tac Toe to make student understand in present tense, so that students be more enjoy in the teaching learning process. Tic Tac Toe game is a board game that using sign $\mathrm{O}$ and $\mathrm{X}$. In this part where $\mathrm{O}$ and $\mathrm{X}$ are one of way to sign in playing the game, it will make a line. This game can be applied in teaching learning process to make students understand on present tense. Here, the game is used to deliver the materials in order to be more fun for students in the process of teaching learning, so they will be enthusiastic in joining the activity. It is important to use game as an alternative way in teaching grammar. This way can make students also have chance to respond or correct other friends on their exercise. In Tic Tac Toe game, there is any competition and cooperative with team that can make students more be enthusiasm and active in learning.

Using media in game Tic Tac Toe game would be allowed more than one-way communication, the teachers not only give verbal stimulus but also gave a stimulate students to shows their main-set their own. So, in addition allows teachers to explain the subject, the materials by using Tic Tac Toe game also can be attract the attention of the students and can prevent students bored among the material giving in classroom.

Based on the description above, the writer is interested in studying about the effectiveness of Tic Tac Toe game in students understanding on simple present tense at the first grade SMP N 1 Aimas, Sorong. Hopefully, this technique can be an effective learning technique in teaching simple present tense and the student more active in learning process.

\section{CONCLUSION}

After conducting the research and calculating the data, the researcher is going to make the conclusion. Using Tic Tac Toe game in teaching learning process was raising than using conventional method and it can help the students more be easier to understanding on simple present tense. The result of the data from the pre-test in experiment class showed the mean score was 61,33 and the mean score of control class was 45,5. It means there some students still did not understand what the simple present tense is. Tic Tac Toe game is working and can makes students understand on simple present tense in learning English. It showed by the result of score where the researcher was found it. The student more be enjoyed and can cooperate with their groups to play this game. It seems different than control class, where they do not using game in learning process. On experiment class post-test showed the mean score was 73,33 and control class on post-test showed the mean score was 56,33. It means on experiment class have been raising than on control class. The result of calculation 
shows from the data analysis where is $=$ is accepted if $t_{\text {test }} \geq t_{\text {table }}$ and is refused if $t_{\text {test }} \leq t_{\text {tableso, }}$, the result of $t_{\text {test }}$ compared with $t_{\text {table }} \mathrm{a}=0,05(5 \%)$ and the result is test $4,598 \geq$ table 2,000 . It means that there is significant differences between experiment and control group which it provided with the treatment Tic Tac Toe game in teaching learning.

\section{REFERENCES}

Arikunto, S. (2010). Prosedur Penelitian Suatu Pendekatan Praktik. Jakarta :Rineka Cipta.

Azzar \& Betty, S. (1985). Fundamentals of English Grammar. New Jersey : Prentice - Hall

Booji, G. (2007). The Grammar of Words An Introduction to linguistic Morphology. New York: OxfordUniversity Press

Brown, H. D .(1988). Principles of Language Learning and Teaching. New Jersey: Prentice-Hall.

Cahyono, at.all. (2011). The Teaching of English as a Foreign Language in Indonesia. Malang: State University of Malang Press.

Gay, L.R. (1992). Educational Research Competencies for Analysis and Application (fourth ed.). New York : Macmillan, Inc.

Kim, L. S. (1995). Creative Games for The Language Class. Forum. 33,(1).

Qomariah, N. (2010). The Effectiveness of Teaching Simple Present Tense Using Card Game: An Experimental Research At The First Grade Of MTs. Darul Ulum Purwogondo Kalinyamatan Jepara In Academic Year of 2009/ 2010. English Departement Tarbiyah Faculty: Walisongo State Institute For Islamic Studies Semarang.

Richard, J. C and Rodgers, T. S. (2001). Approach and Methods in Language Teaching. Cambrifge, UK:Cambridge University.

Rodgers \& Brown. (2002). Doing Second Language Research. Cambridge : Oxford Press.

Sugiyono. (2009). Metode Penelitian Kuantitatif Kualitatif Dan R\&D. Bandung : Alfabeta. 
Thornburry, S. (2006). Research Book for Teachers: Grammar. Publisher Oxford University Press. 11.

Thomson, A. J and A. V Martinet.. (1986). A Practical English Grammar. Oxford :University Press. 